\title{
Analysis of Patient Operation Interest in Sumber Glagah Hospital, Mojokerto Regency
}

\author{
Mohamad Rofi'in ${ }^{1}$, Sentot Imam \\ Suprapto ${ }^{2}$ \\ ${ }^{1}$ Sumber Glagah General Hospital \\ Mojokerto Regency \\ ${ }^{2}$ Institute of Health Sciences \\ Strada Indonesia, Kediri \\ Email: \\ mrofiin1972@gmail.com
}

Received : October $4^{\text {nd }} 2021$

Accepted : October $15^{\text {rd }} 2021$

Published : November $27^{\text {th }} 2021$

\begin{abstract}
A person's interest in services is related to the ability of the service provider to provide services. The purpose of this research is to analyze the influence of perception, service quality, anxiety and type of surgery on patient interest in performing surgery at Sumber Glagah Hospital, Mojokerto Regency. The design of this study is a quantitative analytic study with a cross sectional approach with the focus of the research being aimed at analyzingthe influence of perception, service quality, anxiety and type of surgery on patient interest in performing surgery at Sumber Glagah Hospital, Mojokerto Regency with a population of a number 143 respondents and a sample of 105 respondents who were taken using purposive sampling technique. Data analysis using Linear Regression test.The findings found that Most of the respondents had the perception of a sufficient category as many as 65 respondents (61.9\%). Most of the respondents had a sufficient service quality category as many as 66 respondents $(62.9 \%)$. Most of the respondents had moderate anxiety as many as 61 respondents (58.1\%). Most of the respondents had a selective category of operation as many as 92 respondents $(87.6 \%)$. Most of the respondents have a moderate interest category as many as 69 respondents (65.7\%). Based on the results of the Multiple Linear Regression analysis, it shows that with a p-value of $0.000<0.05, \mathrm{H} 1$ is accepted so it can be concluded that simultaneously there isinfluence perception, quality of service, anxiety and type of surgery on patient interest in performing surgery at Sumber Glagah Hospital, Mojokerto Regency with a magnitude of influence $70.4 \%$. Basically, a person's interest can be influenced by various factors ranging from the patient's point of view, the quality of existing services and even the patient's level of anxiety.
\end{abstract}

Keywords: Type of operation, anxiety, interests, service quality $\&$ perception

Copyright @ 2021 IIK STRADA Indonesia All right reserved.

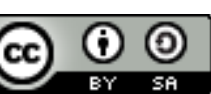

This is an open-acces article distributed under the terms of the Creative Commons AttributionShareAlike 4.0 International License.

\section{INTRODUCTION}

A person's interest in services is related to the ability of the service provider to provide satisfaction. Consumer satisfaction can be defined as big quality or broad quality (satisfaction broadly). This broad satisfaction is related to overall quality concerning service quality, financing, 
distribution channels, safety assurance of use and aspects of morality / performance of employees of a health service organization. Public interest in utilizing outpatient services is influenced by several factors, including the patient's perception of the quality of outpatient services at the Puskesmas (Depkes RI, 2013).

Surgery or surgery is all treatment that uses an invasive way by opening or exposing parts of the body (LeMone and Burke, 2014). In general, this is done by making an incision on the part of the body to be treated, then corrective action is taken and ends with closing and suturing the wound. (Syamsuhidajat, 2010). Surgery is performed to diagnose or treat a disease, injury or disability, and treat conditions that are difficult or impossible to cure with just simple drugs (Potter and Perry 2016).

Surgery is an action that is very much needed by the world of health around the world. Data from the Indonesian Ministry of Health (2019) states that as many as 234 million operations are estimated to be carried out every day around the world.

Based on the results of a preliminary study conducted by researchers on February 17, 2020 at Sumber Glagah Hospital, Mojokerto Regency to 10 patients, it was found that a total of 7 respondents (70\%) had a low interest in having the courage to do surgery where this was due to the patient's perception that the operation would be worsening of the patient's condition, and also the patient's high anxiety of being afraid if the operation process fails. While a number of 3 respondents (30\%) have a high interest where it is because the patient feels confident in the handling of health workers for the good of the patient.

Patients are individuals with emotional needs, and nursing is an interpersonal and therapeutic process in which nurses have an important role in influencing, reducing anxiety and improving patient health through the communication process (Potter \& Perry, 2015). According to Stuart and Sunden, stated that therapeutic communication can increase openness between nurses and clients so that it can reduce anxiety (Hidayat, 2017).

The way nurses assist patients while in the hospital cannot be separated from the patient's view of the nursing services provided by nurses. The patient's view of the services provided is related to the patient's perception of the service. The characteristics of nursing services are perceived by the patient actively as long as the patient will undergo surgery in the hospital. The results of the patient's perceptions can cause various responses which can then affect the emergence of patient anxiety (Nuralita, 2017).

The surgical procedure will provide an emotional reaction for patients who undergo it. One form of emotional reaction that occurs is anxiety. The anxiety that arises will affect the patient's physical and psychological changes which result in the activation of the sympathetic autonomic nerve which is marked by an increase in heart rate, blood pressure, and respiratory rate and in general reduces the energy level in the patient which ultimately harms the patient himself because it will have an impact on the operation. Anxiety that occurs in patients can be caused by the patient's ignorance of the experience of the surgical procedure and the surgical procedure that will be undertaken (Muttaqin \& Sari, 2014).

Arisandi, Sukesi, \& Solechan (2014) in their research on the effect of giving informed consent on anxiety levels in preoperative patients at Tugurejo Hospital Semarang found that all respondents experienced anxiety with the majority of respondents (91.2\%) experiencing severe anxiety and the rest experiencing moderate anxiety. . The results of this study are also in line with the results of research conducted by Budikasi, Mulyadi, \& Malara (2015) which states that all patients undergoing surgery experience anxiety with $36.7 \%$ of them being severe anxiety. Therefore, nurses as health workers who have had the longest contact with patients are expected to be able to provide psychological medicine for patients by increasing patient knowledge about surgical procedures (Mundakir, 2016).

Good physical and mental preparation for patients who are going to undergo surgery is very important to note because the success of a surgery begins with the success of the preparations made during the preoperative stage. Failure in the intraoperative phase may occur due to poor preparation for surgery (Smeltzer \& Bare, 2014). Preoperative nursing is a nursing action performed by nursing professionals in order to prepare patients both physically and mentally with the aim of ensuring patient safety during surgery or in the intraoperative phase (Smeltzer \& Bare, 2014). Qosim (2013) in his research on nursing actions received by preoperative patients in the surgical ward of Dr. 
Qosim (2013) in his research on nursing actions received by preoperative patients in the surgical ward of Dr. Kariadi Semarang said that the patient who will undergo surgery at Dr. Kariadi Semarang $87 \%$ have given informed consent. Informed consent is very important in terms of legal aspects, responsibilities and accountability of health workers towards patients. This is in accordance with the theoretical concept of Smeltzer \& Bare (2014) that every medical action given to a patient must be informed to the patient beforehand because the patient has the right to accept or reject the medical treatment given to him.

Based on the above conditions, the researcher is interested in researching the analysis of perceptions, service quality, anxiety and the type of surgery on the patient's interest in performing surgery at Sumber Glagah Hospital, Mojokerto Regency.

\section{MATERIALS AND METHODS}

In this study, researchers used an observational quantitative design with a cross sectional approach, which is a study to study the dynamics of the correlation between risk factors and effects, by approaching, observing or collecting data at once (point time approach), that is, each subject. The study was only observed once and measurements were made of the character status or subject variables at the time of examination. This does not mean that all research subjects were observed at the same time (Soekidjo, 2012). This research will analyzeperceptions, quality of service, anxiety and types of surgery on patient interest in performing surgery at Sumber Glagah Hospital, Mojokerto Regency.

The total population of 143 respondents and a sample of 105 respondents who were taken using purposive sampling technique. Data analysis using Linear Regression test.

\section{RESULTS}

Table 1. Results of linear regression analysis analysis of perceptions, service quality, anxiety and types of surgery on patient interest in performing operations at Sumber Glagah Hospital, Mojokerto Regency which was held on December 22, 2020 - January 20, 2021 with 105 respondents

\begin{tabular}{ccccc}
\hline Variable & Sig & B & $\boldsymbol{R}^{\mathbf{2}}$ & Sig \\
\hline (Constant) & 0.003 & 2,333 & & \\
Perception & 0.004 & 0.126 & 0.704 & 0.000 \\
Service Quality & 0.001 & 0.420 & & \\
Worry & 0,000 & 1,042 & & \\
Type of Operation & 0.079 & 0.511 & & \\
\hline
\end{tabular}

\section{Partial}

a. The Effect of Perception on Interests

Based on the results of Linear Regression analysis, it shows that the p-value is $0.004<0.05$, then H1 is accepted, so it can be concluded that partially there is influence perceptions of patient interest in performing surgery at Sumber Glagah Hospital, Mojokerto Regency

b. The Effect of Service Quality on Interests

Based on the results of Linear Regression analysis, it shows that the p-value is $0.001<0.05$, then $\mathrm{H} 0$ is rejected and $\mathrm{H} 1$ is accepted, so it is concluded that partially there is influence quality of service for patient interest in performing operations at Sumber Glagah Hospital, Mojokerto Regency

c. Effect of Anxiety on Interests

Based on the results of Linear Regression analysis, it shows that the p-value is $0.00<0.05$, then $\mathrm{H} 0$ is rejected and $\mathrm{H} 1$ is accepted, so it is concluded that partially there is influence anxiety about the patient's interest in performing surgery at Sumber Glagah Hospital, Mojokerto Regency

d. Effect of Type of Operation on Interest

Based on the results of Linear Regression analysis, it shows that the p-value is $0.079>0.05$, so H0 is accepted and $\mathrm{H} 1$ is rejected, so it is concluded that partially there is no influence type of surgery on patient interest in performing surgery at Sumber Glagah Hospital, Mojokerto Regency. 


\section{Simultaneously}

Based on the results of the Multiple Linear Regression analysis, it shows that with a p-value of $0.000<0.05, \mathrm{H} 1$ is accepted so it can be concluded that simultaneously there is influence perception, quality of service, anxiety and type of surgery on patient interest in performing surgery at Sumber Glagah Hospital, Mojokerto Regency with a magnitude of influence $70.4 \%$.

\section{DISCUSSION}

\section{A. Perceptions of Patients in Conducting Operations at Sumber Glagah Hospital, Mojokerto} Regency.

The results showed that most respondents had a sufficient category perception as many as 65 respondents $(61.9 \%)$. In addition, a number of 27 respondents $(25.7 \%)$ had a perception of the poor category. Meanwhile, a number of 13 respondents $(12.4 \%)$ had a good category perception.

Service is an activity or a series of invisible (intangible) tools, which occurs as a result of interactions between consumers and employees or other things provided by service providers intended to solve consumer problems (Ratminto and Winarsih, 2015) .

People as consumers certainly want quality service. Service quality is defined as the level of excellence expected and control over that level of excellence to fulfill customer desires (Dimas and Oktafani, 2014). Service quality can be interpreted as an effort to fulfill the needs and desires of consumers and the accuracy of their delivery in balancing consumer expectations (Dimas and Oktafani, 2014).

Good service is health service that is available in the community (acceptable) as well as sustainable. This means that all types of health services needed by the community are found and their presence in the community is available at any time of need. Health services must be appropriate and acceptable by the community. This means that health services can overcome health problems faced, do not conflict with customs, culture, beliefs and beliefs of the community, and are unnatural, are not a condition of good health services (Suryono, 2013).

The objectives of outpatient services include providing consultation to patients who require the opinion of a specialist, whether or not to take medication and to provide follow-up for inpatients who have been discharged but whose health conditions still need to be controlled. Outpatient care should have a comfortable and pleasant environment for patients. This is important to note because it is from outpatient care that the patient gets the first impression about the puskesmas. A good outpatient environment should be spacious enough and have good air circulation, comfortable seating, attractive furniture and no disturbing noises.

Based on the results of the study, it was found that many respondents had perceptions in the poor category. Where this is because the patient's expectations do not match the reality of the services provided by health workers. According to respondents, several things that must be improved are related to the patient's trust in the ability of health workers, where most respondents do not believe in the abilities of health workers. This is also because officers are considered to be slow in responding to complaints made by patients. So that the services provided are not in accordance with patient expectations.

B. Quality of Service for Health Officers at Sumber Glagah Hospital, Mojokerto Regency.

The results showed that most of the respondents had a sufficient service quality category as many as 66 respondents $(62.9 \%)$. In addition, a number of 26 respondents (24.8) had poor service quality category. While a number of 13 respondents $(12.4 \%)$ had a good service quality category.

Service is an activity or a series of tools that are invisible (cannot be felt), which occurs as a result of interactions between consumers and employees or other things provided by service providers that are intended to solve consumer problems (Winarsih, 2015).

People as consumers certainly want quality service. Service quality is defined as the level of excellence expected and control over that level of excellence to meet customer desires. Service quality can be interpreted as an effort to fulfill the needs and desires of consumers and the accuracy of its delivery in balancing consumer expectations (Oktafani, 2014).

One of the services that is widely used by the community is health services. Utilization of health services by using the service facilities provided in the form of outpatient care, inpatient care, home visits by health workers or other forms of activity from the utilization of these 
services which are based on the availability and continuity of services, community acceptance and fairness, easily accessible to the community. affordable and good quality (Anwar, 2014).

Good service is health service that is available in the community (acceptable) as well as sustainable. This means that all types of health services needed by the community are found and their presence in the community is available at any time of need. Health services must be appropriate and acceptable by the community. This means that health services can overcome health problems faced, do not conflict with customs, culture, beliefs and beliefs of the community, and are unnatural, are not a good health service condition.

The location is easy to reach by the community, so the distribution of health facilities is very important. Reach helper facilities to determine effective demand. If the facility is easily accessible by means of available transportation, this facility will be widely used. Past user levels and trends are the best indicators of short and long term changes in future demand.

The services provided are affordable (affordable) by the community, where efforts are made to pay for these services in accordance with the economic capacity of the community. Expensive health services may only be enjoyed by some people. And shows the level of perfection of health services provided (quality / quality) and shows the cure and safety measures that can satisfy service users in accordance with predetermined standards.

From the research results, the researcher argues that health services must have various basic requirements, namely basic requirements that give influence to the community in determining their choice of the use of health services. With good service it will attract people to want to use health facilities properly and wisely. In the results of the study, it was found that most of the respondents had a sufficient quality of service, but there were still many respondents who considered the quality of service provided by health workers to patients in the poor category. Where this is because patients consider that health workers are not responsive to immediately providing health services so they tend to be slow.

C. Patient Anxiety in Carrying Out Operations at Sumber Glagah Hospital, Mojokerto Regency.

The results showed that most respondents had moderate anxiety as many as 61 respondents (58.1\%). In addition, a number of 26 respondents (24.8\%) had high category anxiety. Meanwhile, 18 respondents $(17.1 \%)$ had low anxiety.

According to the World Health Organization (WHO), being healthy is improving the human condition, whether physically, spiritually or intellectually, socially and not merely eradicating disease. In improving the human condition, efforts to improve optimal health include efforts to improve health (promotive), prevent disease (preventive), cure disease (curative) and restore health or rehabilitation (Anonymous, 2016).

Surgery or what is called surgery is a medical procedure that can cause anxiety. One of the measures to reduce anxiety levels is to mentally prepare yourself from the patient and the communication provided by the nurse (Potter \& Perry, 2010). But the current phenomenon is that the communication carried out by nurses as the closest person and the one who has been with the patient the longest tends to affect the nurse's task rather than recognizing the patient's anxiety and perception of discomfort causing anxiety (Asmadi, 2015).

Anxiety is an emotion, a feeling that arises as an initial response to psychological stress and a threat to values that are meaningful to the individual. Anxiety is often described as a feeling of uncertainty, doubt, helplessness, restlessness, worry, uneasiness which is often accompanied by physical complaints (Azizah et al, 2016)

Anxiety is something that is always felt by those who will undergo a medical examination, surgery / surgery, including preoperative appendictomy patients. Anxiety is a mental condition filled with worry and tension about what might happen, either related to limited problems or strange things. Common descriptions of anxiety include feeling depressed and uneasy and thinking chaos with lots of regret. This is very influential on the body, so that the body feels shivering, causes a lot of sweat, the heart beats fast, the stomach feels nauseous, the body feels weak, the ability to produce decreases so that many humans escape to the realm of the imagination as a form of temporary therapy (Musfir, 2015).

According to researchers, patients who will perform surgery tend to experience anxiety ranging from high to low intensity. Anxiety experienced by patients can still be considered 
normal if it is not too excessive, even to the point of experiencing trauma and so on. Anxiety itself can arise because it will be handled which is quite tense which will perform surgery on certain body parts. The highest level of anxiety is caused by the patient's fear of mishandling by the officer on the operating table. However, this can be handled by providing education and direction in the preoperative phase to patients.

D. Types of Patient Operations at Sumber Glagah Hospital, Mojokerto Regency

The results showed that most respondents had a selective type of operation as many as 92 respondents $(87.6 \%)$. While a number of 13 respondents $(12.4 \%)$ had the type of operation in the emergency category.

Surgery or surgery is all treatment that uses an invasive way by opening or exposing parts of the body (LeMone and Burke, 2004). In general, this is done by making an incision on the part of the body to be treated, then corrective action is taken and ends with closing and suturing the wound. (Syamsuhidajat, 2010). Surgery is performed to diagnose or treat a disease, injury or disability, and treat conditions that are difficult or impossible to cure with simple drugs (Potter and Perry 2011).

Major surgeries include head, neck, chest and abdominal surgery. Recovery can be lengthy and can involve intensive care within a few days in the hospital. This surgery has a higher risk of complications after surgery (Virgina, 2004).

Major surgery often involves one of the main bodies in the abdominal cavities (laparotomy), in the chest (thoracotomy), or the skull (craniotomy) and can also be on the vital organs. The operation is usually performed using general anesthesia in the hospital operating room by a team of doctors. At least the patient will undergo one night's stay in the hospital after the surgery. Major surgery usually carries some degree of risk to the patient's life, or the potential for severe disability if something goes wrong during the operation. For example in a major surgical procedure there can be significant changes to the anatomy involved. As in situations where organs are removed, or joints are constructed with artificial components. Any penetration of organs is considered major surgery, as is extensive surgery on the bones in the legs. Neurosurgery is generally considered to be primary because of the risks to the patient. Some prime examples of surgery include knee replacements, cardiovascular surgery, and organ transplants. This procedure definitely carries risks to the patient such as infection, bleeding, or complications from causing anxiety in general use.

According to the researchers, the choice of the type of surgery of the patient is due to the patient's own condition, such as if the patient has certain physical abnormalities that are not dangerous, the patient can choose to do surgery or not where it does not affect the patient's survival. Then there are also patients who experience certain disorders that can affect the life of the patient in the future who are recommended for surgery. And there are also patients who can't even choose to do surgery or not because the patient is unconscious so that the family decides to do the surgery or not. The simple thing is that patients have the autonomy of their own to do surgery or not.

\section{E. Patients' Interests in Conducting Operations at Sumber Glagah Hospital, Mojokerto Regency.}

The results showed that most of the respondents had moderate interest category as many as 69 respondents (65.7\%). In addition, a number of 20 respondents (19\%) have a low interest category. Meanwhile, 16 respondents $(15.2 \%)$ have high interest category.

According to Crow and Crow in Djaali (2013), interest is related to the style of motion that encourages a person to face or deal with people, objects, activities, experiences stimulated by the activity itself. According to Gerungan in Djaali (2013), interest is the mobilization of feelings and interpreting for something (there is an element of selection). Besides that, interest is part of the realm of affection, from awareness to value choices. Interest does not arise alone, there is an element of need.

Djaali (2013) concluded that interest has elements of affection, awareness to value choice, mobilization of feelings, selection, and inclination of the heart. Interest can be expressed through a statement which shows that the patient prefers one thing over another, it can also be manifested through participation in an activity. 
Theoretical study of the reuse of the opinion of Zeithalm et al. (2016) stated that future intention emphasizes the importance of measuring customer repurchase interest to find out what customers want to remain loyal or leave a service. From that experienceIt can be noted, the objective of the re-purchase of goods or services is the quantity and quality of the goods or services purchased not to be less. Another thing that is still related to repurchasing is maintaining the quality of goods or services so that they do not decline (Nitisusastro, 2012).

Continuous reuse of the same service will show patient loyalty to that service. The level of patient satisfaction will affect the degree of service quality, the more satisfied a patient is with a service, the more loyal to the service. However, loyalty is often not caused by patient satisfaction but because of compulsion and lack of choice (Sunyoto, 2013).

According to researchers, the interest of a prospective patient who will perform surgery at a health facility is very diverse. Basically, a person's interest can be influenced by various factors ranging from the patient's point of view, the quality of existing services and even the patient's level of anxiety. Of the several respondents who were sampled, most of the respondents had moderate interest, but there were still some respondents who had low interest. Where this is because the respondent lives in an area that is not so close to the hospital and also not so close to a clinic or other doctor's practice. So that patients choose to use this hospital because they want to go to another hospital that is also far away.

F. Influence Perceptions of Patients' Interests in Performing Operations at the Sumber Glagah Hospital, Mojokerto Regency

Based on the results of Linear Regression analysis, it shows that the p-value is 0.004 $<0.05$, then $\mathrm{H} 1$ is accepted, so it can be concluded that partially there is influence perceptions of patient interest in performing surgery at Sumber Glagah Hospital, Mojokerto Regency.

Surgery or surgery is all treatment that uses an invasive way by opening or exposing parts of the body (LeMone and Burke, 2014). In general, this is done by making an incision on the part of the body to be treated, then corrective action is taken and ends with closing and suturing the wound. (Syamsuhidajat, 2010). Surgery is performed to diagnose or treat a disease, injury or disability, and treat conditions that are difficult or impossible to cure with just simple drugs (Potter and Perry 2016).

A person's interest in services is related to the ability of the service provider to provide satisfaction. Consumer satisfaction can be defined as big quality or broad quality (satisfaction broadly). This broad satisfaction is related to overall quality concerning service quality, financing, distribution channels, safety assurance of use and aspects of morality / performance of employees of a health service organization. Public interest in utilizing outpatient services is influenced by several factors, including the patient's perception of the quality of outpatient services at the Puskesmas (Depkes RI, 2013).

Qosim (2013) in his research on nursing actions received by preoperative patients in the surgical ward of Dr. Kariadi Semarang said that the patient who will undergo surgery at Dr. Kariadi Semarang $87 \%$ have given informed consent. Informed consent is very important in terms of legal aspects, responsibilities and accountability of health workers towards patients. This is in accordance with the theoretical concept of Smeltzer \& Bare (2014) that every medical action given to a patient must be informed to the patient beforehand because the patient has the right to accept or reject the medical treatment given to him.

According to researchers, the perspective of the patient is very common. Patients have their own perspective on the services provided by officers. Most of the respondents have the perception that they are in the moderate category and also have moderate interest category. Patients who can have high interest must have a good perception of the surgical services that will be provided to patients. Believing in what health workers are doing is the best that can be done for the survival of future patients. So the conclusion isthere is influence perceptions of patient interest in performing surgery at Sumber Glagah Hospital, Mojokerto Regency.

\section{G. Influence Quality of Service for Patients' Interest in Performing Operations at Sumber Glagah Hospital, Mojokerto Regency}

Based on the results of Linear Regression analysis, it shows that the p-value is 0.001 $<0.05$, then $\mathrm{H} 0$ is rejected and $\mathrm{H} 1$ is accepted, so it is concluded that partially there is influence 
quality of service for patient interest in performing operations at Sumber Glagah Hospital, Mojokerto Regency.

A person's interest in services is related to the ability of the service provider to provide satisfaction. Consumer satisfaction can be defined as big quality or broad quality (satisfaction broadly). This broad satisfaction is related to overall quality concerning service quality, financing, distribution channels, safety assurance of use and aspects of morality / performance of employees of a health service organization. Public interest in utilizing outpatient services is influenced by several factors, including the patient's perception of the quality of outpatient services at the Puskesmas (Depkes RI, 2013).

To retain customers, the hospital is required to always maintain consumer trust by paying close attention to consumer needs in an effort to fulfill the wishes and expectations of the services provided. Hospital consumers, in this case patients who expect health services at the hospital, not only expect medical and nursing services but also expect comfort, good accommodation and harmony between hospital staff and patients, thus it is necessary to improve the quality of health services at the hospital. (Supranto, 2016).

Improving service quality is one of the most crucial issues in management, both in the public and private sectors. This occurs because on the one hand the demands of the community for improving the quality of service from year to year are getting bigger, while on the other hand the practice of service delivery has not experienced significant improvements (Purwoastuti and Walayani, 2015).

Health efforts are aimed at improving the quality of services, equity and coverage of health services. The quality of public health services needs to be continuously improved to improve the health status of the community because the realization of a healthy condition is the will of all parties. To realize this healthy condition, many things need to be done, one of the efforts that are considered to have a fairly important role is the implementation of health services. The success of these efforts can be assessed through improving the quality of services at the primary level (Anggraini and Rohmani, 2012).

Lewis and Booms (2013) define service quality as a measure of how well the level of service provided is in accordance with consumer expectations. Based on this definition, quality of service can be realized through meeting the needs and desires of patients and the accuracy of delivery to match patient expectations. Thus, there are two main factors that affect service quality, namely the expected service and the perceived service (Tjiptono, 2015).

Consumer behavior interest in buying or using services from service providers is strongly influenced by the experience of satisfaction with the services previously provided. After receiving health services, the patient will compare the services received with the services expected. (Rustiyanto, 2011). Therefore, the decrease in the number of old visits shows that the interest in patient visits to return to hospital services has also decreased. Medical personnel services, medics, facilities and infrastructure can also improve the quality of service if users can feel and are interested in reusing these services (Anggraini, 2012). Research results from Trimurthy (2010) show that there is a relationship between interest in reuse and service quality, namely about reliability, responsiveness, direct evidence,

Users of health services in hospitals demand quality services not only regarding recovery from physical illness but also regarding satisfaction with the attitudes, knowledge and skills of officers in providing services and the availability of adequate and comfortable facilities and infrastructure. With the increasing quality of service, the service function in the hospital needs to be improved to be more effective and efficient and to provide satisfaction to patients and the community. The hospital's very heavy function in providing services to the community is faced with several challenges in terms of human resources and increasingly sophisticated health equipment, but must still provide the best service (Khusnawati, 2010).

According to the researcher, there are several things that can influence the patient's interest in visiting a health facility where the health facility must have health workers who have good service so that patients can feel comfortable with the services provided and will reuse them if one day they are sick again. So that researchers argue that there isinfluence quality of service for patient interest in performing operations at Sumber Glagah Hospital, Mojokerto Regency. 


\section{H. Influence Anxiety of Patients' Interest in Carrying Out Operations at the Sumber Glagah Hospital, Mojokerto Regency}

Based on the results of Linear Regression analysis, it shows that the p-value is 0.00 $<0.05$, then $\mathrm{HO}$ is rejected and $\mathrm{H} 1$ is accepted, so it is concluded that partially there is influence anxiety about the patient's interest in performing surgery at Sumber Glagah Hospital Mojokerto Regency.

One of the problems that a person experiences when he is sick is anxiety, especially if that person has to undergo medical action, namely surgery and acts as a patient. Various bad possibilities can occur which will endanger the patient. So do not be surprised if patients and their families often show a somewhat excessive attitude with the anxiety they experience. Anxiety is a common thing in human life. Anxiety can also be a heavy burden that causes the individual's life to be always under the shadow of a prolonged period of anxiety and considers anxiety as a mental tension accompanied by bodily disturbances that cause a feeling of being unaware of threats, anxiety related to physiological and psychological stress. That is,

Preoperative anxiety is caused by several factors, namely fear of pain, death, fear of ignorance, fear of disability and other threats that can impact body image (Muttaqin \& Sari, 2014). Anxiety was found to be the highest in patients with pre-major surgery, while the lowest was found in patients with pre-minor surgery (Wardani, 2012). The longer the patient prepares the ward, the better the patient will be to adjust to the physiological stress of surgery. As in patients with a fear of pain both during surgery and after surgery. An explanation of anesthesia during surgery and the drugs that will be given after the operation is over, as well as techniques to reduce or manage pain can reduce the anxiety of preoperative patients (Digiulio,

In the interpersonal view, anxiety arises from feeling afraid of rejection when dealing with other people. It is also associated with trauma during growing up, such as loss and separation from loved ones. Rejection of self-existence by others or society will cause the individual to become anxious, but if his existence is accepted by others, he will feel calm and not anxious (Yulianto, 2016).

Research conducted by Prasetya (2014), on the relationship between anxiety and interest in preoperative patients in the surgical treatment room of Prof. Dr. Hi. Aloeli Saboe Kota Gorontalo 2014 with a sample size of 35 people. The results showed that most respondents had high anxiety indicating a low interest, namely 26 people (69.6\%), 7 people $(30.4 \%)$ moderate interest and high interest $(0 \%)$.

According to researchers the patient's concernof the success of an operation process is very much felt and the patient tends to very much wish for an unwanted event while on the operating table. Because most patients think that all patients who undergo surgery will be unconscious so the patient cannot know what will happen afterwards. However, high concern can reduce the patient's interest in performing surgical procedures, while patients who are calmer will be optimistic about the success of the operation to become healthier. So it can be concluded that there is an effect of anxiety on the patient's interest in performing surgery at Sumber Glagah Hospital, Mojokerto Regency.

I. The Influence of Types of Operations on Patients' Interest in Performing Operations at Sumber Glagah Hospital, Mojokerto Regency

Based on the results of Linear Regression analysis, it shows that the p-value is $0.079>0.05$, so $\mathrm{H} 0$ is accepted and $\mathrm{H} 1$ is rejected, so it is concluded that partially there is no influence type of surgery on patient interest in performing surgery at Sumber Glagah Hospital, Mojokerto Regency.

According to the Indonesian Surgical Chamber Association (HIPKABI) defines surgery as an invasive medical procedure for diagnosis, treatment of disease, trauma and deformities (HIPKABI, 2014). Another definition states that surgery is an act of surgery on a part of the body (Smeltzer, et al., 2010).

Before surgery, it is important to check general health status, including client identity, medical history such as past health, family medical history, complete physical examination, including hemodynamic status, cardiovascular status, respiratory status, kidney and hepatic function, endocrine function, immunological functions, and others. In addition, patients must have adequate rest because with adequate rest the patient will not experience physical stress, the 
body is more relaxed so that for patients who have a history of hypertension, their blood pressure can be stable and female patients will not trigger menstruation earlier (Smeltzer, 2010).

Shaving in the area of surgery is intended to prevent infection in the surgical area because unshaved hair can be a place to hide germs and also interfere with / hinder the healing and wound care process. However, there are certain conditions that do not require shaving before surgery, for example in patients with an incised arm. The shaving action (scheren) must be done with care not to cause injury to the shaved area. Often times patients are given the opportunity to shave themselves so that the patient feels more comfortable. The area that is shaved depends on the type of operation and the area to be operated on (Surgery, 2010).

The patient's body hygiene is very important in preparation for surgery because a dirty body can be a source of germs and can cause infection in the area being operated on. Patients who are physically strong are advised to bathe themselves and clean the operating area more thoroughly. Conversely, if the patient is unable to meet personal hygiene needs independently, the nurse will provide assistance in fulfilling personal hygiene needs (Mirianti, 2011).

According to researchers, a patient who decides to have surgery in a place can be influenced by many factors, but sometimes there are patients who in an emergency choose to use surgery facilities in the nearest area in order to get treatment as soon as possible. The choice of surgery types ranging from selective types of surgery such as small to large-scale surgery or types of emergency operations such as accidents to childbirth operations does not affect whether the patient chooses to use a health facility according to his wishes. As long as these health facilities are of good quality, patients will use them for all types of health services.

\section{CONCLUSION}

1. Most of the respondents have a sufficient category perception as many as 65 respondents $(61.9 \%)$.

2. Most of the respondents had a sufficient service quality category as many as 66 respondents $(62.9 \%)$.

3. Most of the respondents had moderate anxiety as many as 61 respondents $(58.1 \%)$.

4. Most of the respondents had a selective category of operation as many as 92 respondents $(87.6 \%)$.

5. Most of the respondents have a moderate interest category as many as 69 respondents $(65.7 \%)$.

6. There is influence perceptions of patient interest in performing surgery at Sumber Glagah Hospital, Mojokerto Regency.

7. There is influence quality of service for patient interest in performing operations at Sumber Glagah Hospital, Mojokerto Regency.

8. There is influence anxiety about the patient's interest in performing surgery at Sumber Glagah Hospital, Mojokerto Regency

9. Nothing influence type of surgery on patient interest in performing surgery at Sumber Glagah Hospital, Mojokerto Regency.

\section{SUGGESTION}

1. For Respondents

It is expected that respondents can provide constructive input and criticism so that the services provided can be as expected.

2. For Educational Institutions

It is hoped that educational institutions can use the results of this study as input for learning in the analysis of perceptions, service quality, anxiety and types of surgery on patient interest in performing operations at Sumber Glagah Hospital, Mojokerto Regency and can be developed again for further research to make it more useful for readers and researchers. .

3. For Further Researchers

It is hoped that future researchers need to be deepened and added with more specific research about analysis factors affecting satisfaction patients during surgery at Sumber Glagah Hospital, Mojokerto Regency. 


\section{ACKNOWLEDGMENT}

I state truthfully that to the best of my knowledge, in this thesis manuscript there are no scientific works that have been submitted by other people to obtain an academic degree in a university, and there are no works or opinions that have been written or put in order by people. other, except those quoted in writing in this text and mentioned in the sources of citations and bibliography.

\section{CONFLICT OF INTEREST}

In this research, there is no interest whatsoever related to myself or with other institutions apart from the Strada Indonesia Institute of Health Sciences, Kediri City.

\section{REFERENCES}

Anggraini Santi, Siagian, Sondang (2012). Teori Koordinasi dan Aplikasinya, Jakarta : Rinka Cipta

Anwar Madunde K. (2013). Faktor-faktor yang Berhubungan dengan Pemanfaatan Pelayanan Kesehatan di Puskesmas Kema Kecamatan Kema Kabupaten Minahasa Utara. Fakultas Kesehatan Masyarakat Universitas Sam Ratulangi.

Asmadi, Dewy (2015) Analisis Pengaruh Tingkat Kualitas Pelayanan Jasa Rumah Sakit Terhadap Kepuasan Pasien,. Skripsi Fakultas Ekonomi Universitas Diponegoro.

Azizah, dkk. (2016) Organisasi : Perilaku, Struktur, Proses, Edisi Kelima, Jilid 1, Alih Bahasa Djarkasih, Erlangga, Jakarta

Budikasi, Mulyadi, \& Malara (2015) Perilaku Organisasi. Jakarta : Penerbit IPPSDM-WIN.

Dimas dan Oktafani. (2014). Hubungan Kualitas Pelayanan Dengan Minat Pemanfaatan Kembali Pelayanan Kesehatan Di Puskesmas Jongaya Kota Makasar

Hidayat (2016). Performance Appraisal. PT. Raja Grafindo Persada: Jakarta.

Mundakir. (2016) Organisasi : Perilaku, Struktur, Proses, Edisi Kelima, Jilid 1, Alih Bahasa Djarkasih, Erlangga, Jakarta

Muttaqin \& Sari (2014) Psikologi Industri, Seri Ilmu Sumber Daya Manusia. Edisi ke empatYogjakarta : Penerbit Liberty.

Nitisusastro Ndraha Sucipta (2012). Manajemen Pendidikan dan Kesehatan. Cetakan I. Jakarta : Sagung Seto.

Nuralita Muninjaya, A.A. Gde. (2017). Manajemen Mutu Pelayanan Kesehatan. Jakarta:Kedokteran EGC.

Potter Perry (2016) Determining quality of publichealth care services in rural India; Clinical Governance: An International Journal Vol. 16 No. 1, pp. 35-49.

Purwoastuti dan Walayani (2015) Manajemen SDM dalam Publik dan Bisnis, Cetakan Kedua, Jakarta : Alfabeta.

Qosim (2013) Perilaku, Struktur, Edisi Ketiga, Jilid 1, Alih Bahasa Djarkasih, Erlangga, Jakarta

Qosim Sangadji, E.M, Sopiah. (2013). Perilaku Konsumen. Yogyakarta:Andi.

Ratminto dan Winarsih. (2015). Faktor-Faktor Yang Berhubungan Dengan Minat Kunjungan Ulang Pelayanan Antenatal Di Poliklinik Kebidanan Rs Islam Sunan Kudus. Artikel Ilmiah. Magister Ilmu Kesehatan Masyarakat Universitas Diponegoro : Semarang

Ratminto dan Winarsih. (2015). Hubungan Persepsi Mutu Pelayanan Asuhan Keperawatan Dengan Kepuasan Pasien Rawat Inap Kelas III di RSUD Wangaya Kota Denpasar. pp. 1. Pascasarjana,Denpasar:Universitas Udayana.

Rustiyanto Swarburg RC, (2011). Hubungan Pemenuhan Kebutuhan Tenaga Kerja Dengan Motivasi Kerja, Buku Kedokteran EGC, Jakarta

Smeltzer \& Bare (2014). Teori Koordinasi dan Pengukurannya. Jakarta. Bumi Aksara.

Soekidjo. (2013). Konsep dan Penulisan Riset Kesehatan. Yogyakarta : Graha Ilmu

Sunyoto Marr, Heather dkk, (2013) Penjaminan Kualitas Dalam Keperawatan, Konsep, Metode dan Studi Kasus, Penerbit Buku Kedokteran, Jakarta.

Suryono (2013). Manajemen pengembangan sumberdaya manusia. Jakarta: PT.Rajagrafindo Persada. Tjiptono (2015) Manajemen Kinerja Edisi 3, jakarta PT. Raja Grafindo Persada. 